\title{
Short term outcome of congenital hyperinsulinism: case series
}

\author{
Song Hai Lim", Janet YH Hong ${ }^{1}$, MZ Fuziah', S Flanagan², S Ellard², K Hussain² \\ From 7th APPES Biennial Scientific Meeting \\ Nusa Dua, Bali. 14-17 November 2012
}

\section{Introduction}

Congenital hyperinsulinism $(\mathrm{CH})$ is a major cause of recurrent hypoglycaemia in neonates and infants, results in varying degrees of neurological impairment. Advances in molecular study and imaging technique have been used to guide treatment option for $\mathrm{CH}$. However, there were centres treating $\mathrm{CH}$ with long-term medications and reported good neurodevelopmental outcome.

\section{Objective}

To describe short-term outcome of infants with $\mathrm{CH}$ in Putrajaya Hospital, Malaysia.

\section{Method}

Medical data of all patients diagnosed with $\mathrm{CH}$ between 15 October 2007 and 31 December 2011 was retrieved from electronic medical record. Their clinical features and treatment outcome were reviewed. Genetic study was performed in Exeter, United Kingdom.

\section{Results}

Five infants were reported. Hypoglycaemic seizure was the commonest presenting feature. All had detectable insulin level $(>5 \mathrm{mU} / \mathrm{l})$ during hypoglycaemic episodes and high glucose requirement ( $>10 \mathrm{mg} / \mathrm{kg} / \mathrm{min}$ ). Three patients were found to have genetic mutation associated with $\mathrm{CH}$. Patient 1 had hyperammonaemia hyperinsulinism syndrome and corresponded missense mutation of GLUD1 gene. For past 2.5 years, there was good response to diazoxide treatment. Patient 2 had diffuse disease with homozygous mutation at the $A B C C 8$ gene. She presented at birth with severe disease and required combination of medications including octreotide. It was complicated by epilepsy, and developmental milestones were mildly delayed. Patient 3 inherited a heterozygous mutation in the KCNJ11 gene from the father (presumed focal disease). He responded only to octreotide and showed normal development at nine months old. Another two patients had no common mutation detected. Patient 4 required combination of therapy initially, but subsequently treated with diazoxide alone and weaned off nasogastric feeding at five years old. Patient 5 had features suggestive of Beckwith-Wiedemann syndrome and did not respond to all medical therapy. Pancreatectomy was performed at 3 months old and he died from complications of surgery.

\section{Conclusion}

Molecular genetic study is useful in the management of neonates and infants with $\mathrm{CH}$. Patients with focal and diffuse disease were shown to respond to medical therapy.

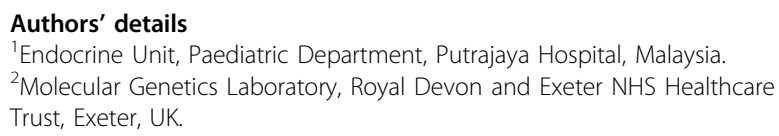

Published: 3 October 2013

doi:10.1186/1687-9856-2013-S1-P176

Cite this article as: Lim et al:: Short term outcome of congenital hyperinsulinism: case series. International Journal of Pediatric Endocrinology 2013 2013(Suppl 1):P176. 